BACTERIAL PHYSIOLOGY

\title{
Environment shapes magnetic personality
}

\section{ce}

the mineral

composition of

magnetosomes

is likely to be

affected by

environmental

parameters
Some aquatic bacteria orient and swim along geomagnetic fields by producing magnetosomes - intracellular, membrane-bound magnetic crystals made of the minerals magnetite $\left(\mathrm{Fe}_{3} \mathrm{O}_{4}\right)$ or greigite $\left(\mathrm{Fe}_{3} \mathrm{~S}_{4}\right)$. Although a number of magnetiteproducing species have been isolated and characterized, no greigiteproducing species have been isolated and grown in pure culture.

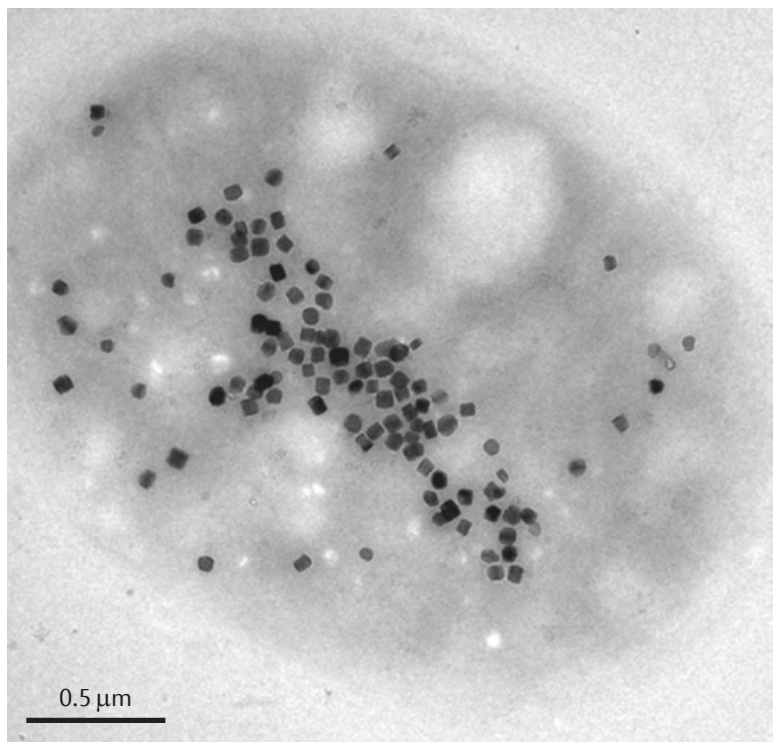

A greigite-producing magnetotactic bacterium from Badwater Basin, Death Valley National Park, California, USA. Image courtesy of C. T. Lefèvre, Centre National de la Recherche Scientifique, France, and D. A. Bazylinski, University of Nevada at Las Vegas, USA.
Lefèvre et al. collected water and sediment samples from a range of freshwater, brackish and hypersaline environments in the southwestern United States and then magnetically enriched and purified magnetosomeproducing bacteria. They observed a range of large magnetotactic, rodshaped bacteria, each possessing a single polar flagellum. Interestingly, whereas some cells contained either greigite or magnetite, others contained both minerals, as determined by selected-area electron diffraction during electron microscopy. Analysis of the $16 \mathrm{~S}$ ribosomal RNA gene sequences of the purified bacteria revealed that they collectively form a distinct, previously undescribed clade of sulphate-reducing bacteria within the class Deltaproteobacteria.

The authors attempted to cultivate the purified bacteria under a range of media conditions, observing growth of a few isolates in anaerobic complex liquid media. After several rounds of dilution to extinction, the authors obtained two pure cultures: strain SS-2 from the Salton Sea, California, USA, and strain BW-1, from Badwater Basin, California, USA. Whereas SS-2 produced only magnetite-containing magnetosomes under culture conditions, BW-1 produced chains of magnetosomes containing greigite and/or magnetite. Importantly, the mineral composition of the magnetosomes in $\mathrm{BW}-1$ correlated with levels of $\mathrm{H}_{2} \mathrm{~S}$ in the culture medium: when $\mathrm{H}_{2} \mathrm{~S}$ accumulated in the media, greigite was biomineralized, whereas when $\mathrm{H}_{2} \mathrm{~S}$ levels were kept low by regular purging of the culture headspace, magnetite was biomineralized. The authors sequenced some of the magnetosome (mam) genes in BW-1 and found that two copies of most mam genes were present, separated into two gene clusters. The genes in the first of these clusters were most similar to those of the magnetite-producing species Desulfovibrio magneticus, whereas the genes in the second cluster were most similar to those of the greigiteproducing species 'Candidatus Magnetoglobus multicellularis'.

These findings indicate that the mineral composition of magnetosomes is likely to be affected by environmental parameters and that distinct magnetite- and greigitespecific gene clusters allow magnetotactic behaviour under different environmental conditions.

Andrew Jermy

ORIGINAL RESEARCH PAPER Lefèvre, C. T. A cultured greigite-producing magnetotactic bacterium in a novel group of sulfate-reducing bacteria. Science 334, 1720-1723 (2011) 